\title{
INCOME AND ENERGY SOURCES AMONG AGRARIAN HOUSEHOLDS IN NIGERIA: IMPLICATIONS FOR LOW CARBON ENERGY DEVELOPMENT IN LESS DEVELOPED COUNTRIES
}

\author{
M. Mkpado ${ }^{1}$, J.N. Nweze ${ }^{2}$, E.M. Igbokwe ${ }^{3}$, Researchers \\ ${ }^{1}$ Federal University Oye-Ekiti, Ekiti State, Nigeria \\ ${ }^{2}$ Department of Agric. \& Bio-Resource Engineering, UNN \\ ${ }^{3}$ Centre for Rural Development and Cooperatives and \\ Department of Agricultural Extension, UNN \\ Phone: +2 (348) 035813278, E-mail: mkpado@gmail.com, manotejah341@yahoo.com
}

Received July 8, 2012

\begin{abstract}
Low-carbon power comes from sources that produce fewer greenhouse gases than do traditional means of power generation. It includes zero carbon power generation sources, such as wind power, solar power, geothermal power and (except for fuel preparation) nuclear power, as well as sources with lower-level emissions such as natural and petroleum gas, and also technologies that prevent carbon dioxide from being emitted into the atmosphere, such as carbon capture and storage. This article correlated value of income from different sources to energy sources used by agrarian households in Nigeria and drew implications for low carbon development in Africa. It analysis included use of wind power for irrigation purposes, harnessing solar energy for lightening and possible cost implications. Secondary data were collected from Community Based Monitoring System Nigeria Project. Descriptive statistics, correlation and qualitative analysis were employed. The average annual income of agrarian households from different sources such as crop farming, livestock farming, petty trading, forest exploitation, remittance and labour per day was below the poverty line of $\$ 1$ per day. The source of energy that had the highest number of significant correlation was electrical energy (low carbon electrical energy). It showed the possibility of pooling resources as farmers group to attract grants or equity financing to build wind mills for irrigation. The study recommended use of energy efficient bulbs to reduce $\mathrm{CO}_{2}$ emissions. This requires creating awareness among rural dwellers of the need to make such change.
\end{abstract}

\section{KEY WORDS}

Poverty; Agriculture; Low carbon energy; Environment.

Agriculture constitutes approximately 30\% of Africa's GDP and contributes about $50 \%$ of the total export value, with $70 \%$ of the continent's population depending on the sector for their livelihood (CEEPA, 2002). Agricultural production is subsistence in nature with a high dependence on the rain. The debate on climate change and its impacts on agriculture are therefore very crucial to the very survival of the continent and its people. The continent is particularly susceptible to climate change because it includes some of the world's poorest nations (CEEPA, 2002). Such nations have very low capacity to cope with climate change.
Majority of the farmers are poor and live in rural areas. They engage in small-scale crop farming and livestock keeping as well as earn income as agricultural labourers. Thus, African dependence on agriculture for their livelihoods cannot be overemphasized. Agriculture is known to contribute to climate change in five major ways, and agricultural production is estimated to be responsible for $28 \%$ of global GHG emissions. (Funde, Fjalland, Ravnborg and Egelyng, 2009). The mechanisms by which agriculture contributes to GHGs emissions as outlined by Eboh (2011) include: (a) Land conversion to agriculture, (b) manufacture and distributions and use of synthetic fertiliser - 0.6-1.2\% of world's total GHGs 
emissions (c) industrial agricultural production methods (d) deforestation, and (e) poor agricultural land management, which leads to depletion of carbon stocks - above and below ground. Agricultural emissions of nitrous oxide are projected to increase $35-60 \%$ by 2030 due to increased nitrogen fertiliser use and increased animal manure production, while methane emissions related to global livestock production are also projected to increase by $60 \%$ by 2030 (FAO, 2003).

As more knowledge becomes available, for instance regarding the disruptive effects of biofuels and pesticides, agriculture's actual contribution may turn out to be significantly higher. Options for climate change mitigation in agriculture already exist and include (i) sustaining and enhancing soil carbon storage capacity and thereby water-holding capacity; (ii) reducing emissions from pesticide application; (iii) integration of crop and animal production; and (iv) reducing the production, transport and use of synthetic nitrogen fertilizers. (Funde, Fjalland, Ravnborg and Egelyng, 2009).

Apart from greenhouse gas emitted by agricultural activities, energy consumptions by farming households are another source of greenhouse gas emission. According to data from the World Resources Institute, energy production and consumption are the main causes of global GHG emissions on the global scale, responsible for an estimated $63 \%$ of global greenhouse gas (GHG) emissions . Not surprisingly, therefore, increasing the efficiency of energy use and the reliance on renewable energy sources has been the main focus for climate change mitigation (Funde, Fjalland, Ravnborg and Egelyng, 2009). The picture for less developed countries (LDCs) differs significantly from these global averages. In LDCs, energy production and consumption are responsible for only $6 \%$ of total GHG emissions, while land-use change and forestry is responsible for $74 \%$ of GHG emissions (Funde, Fjalland, Ravnborg and Egelyng, 2009).

However, higher revenues from oil and gas have not led to a reduction in poverty. The government is committed to a liberal economy, with a market-determined exchange rate, fiscal prudence, decentralization, privatization and progressive reform of the financial sector. Inflation is on a downward trend and was estimated at 7.2 per cent at the end of 2007. The government received debt relief in 2005/2006 and by May 2007 had paid off its accumulated debt in full. Agriculture contributes to development in several ways. For instance, as an economic activity, agriculture is a source of growth for the hydro economy, a provider of investment opportunities for the private sector and a prime driver of agriculturerelated activities and industries and the rural nonfarm economy. Agricultural production is important for food security because it is a source of income for most of the rural poor. Between 1990 and 2005, agriculture value added (AVA) rose by an average of four percent each year; for the period, 2003 to 2005, AVA represented US $\$ 16.46$ billion and accounted for $22.1 \%$ of GDP. Agriculture is the source of livelihood for the majority of rural people, providing jobs for smallholders and landless labourers and a foundation for viable rural communities (WDR, 2008; IFAD, 2009)

The agricultural sector is typified by the predominance of smallholders: $90 \%$ of the country's food was produced by small-scale farmers on small plots of land. More than half of all farmers grow only food crops and women play a greater role in processing and marketing than men. Around $44 \%$ of male farmers and $72 \%$ of female farmers cultivate less than one hectare per household. The sector comprises an arable land area of over 70 million hectares, of which only $50 \%$ is under cultivation; an inland water body area of just over 12 million hectares, which is important for both farming and fishing; and lowlying, seasonally flooded areas that are used increasingly for rice. In the northern zone, sorghum, millet, sesame, groundnuts and cotton are grown. This is also the main livestock-raising area, where over $75 \%$ of small ruminants and cattle, camels and donkeys are bred. In the central belt and south-west, root and tuber crops, maize, plantain and sorghum are most commonly cultivated. Cash and export crops are produced mainly in the south-west and south-east: cocoa, oil palm, rubber and citrus fruits, and fisheries is also a major activity. Nigeria is the largest producer of yam and cowpea in Africa, the world's leading producer of cassava and a major fish producer, with annual outputs of over 300,000 tons (IFAD, 2009).

Since agricultural activities emit green house gasses as well as other aspects of farmers' livelihood there is need to examine energy usage among farmers. This will help to develop low carbon energy options for farmers in order to limit the possible greenhouse gas emitted from far- 
mers business and domestic affairs. The paper thus examined available energy sources used by farmers and determinants of the choice. It further examined options for pooling resources to fund more efficient energy sources to encourage low carbon energy development. It was hypothesised that income, education, age and household size do not affect choice access to energy sources.

Basic concepts. Low carbon development refers to an economic development process which minimizes the output of GHG emissions into the atmosphere. In addition to such a development process, there may then be a number of positive effects on poverty alleviation, although importantly it should not be assumed that these come automatically from a low carbon development process. Access to energy services plays a vital role in many aspects of poverty alleviation and sustainable development in general. Although energy is not mentioned explicitly in any of the Millennium Development Goals, access to clean and reliable energy is a prerequisite for the achievement of most of them, as described in the text box below ( DFID 2002). Some small and medium scale enterprises (SMEs) which include agriculture can have achieved impressive scales in low carbon energy access and technology promotion as a result contribute to well-being, poverty reduction and wider environmental benefits. According to the Intergovernmental Panel on Climate Change (IPCC), "Climate change may be due to natural internal processes or external forcings, or to persistent anthropogenic changes in the composition of the atmosphere or in land use" (IPCC, 2007). A change of climate can be attributed directly or indirectly to human activity that alters the composition of the global atmosphere and which is in addition to natural climate variability observed over comparable periods of time. Access to energy influences small scale farmers' standard of living. The magnitude of money they spend can limit their welfare in other areas. Household in Loess Hilly Region of Gansu Province, China spend about $8.69 \%$ of household net income on commercial energy (Guozhu, et al. 2009). This has implications on their net savings for investment.

\section{METHODOLOGY}

The study area. Nigeria lies on the coast of West Africa and occupies a land area of 924,000 $\mathrm{km}^{2}$. According to the provisional results of the
2006 census, it has a population of 140 million (NPC, 2007), making it one of the largest and politically a very important nation in Africa. The country has a decentralized federal system of government comprising a federal capital territory (FCT), 36 states and 774 LGAs. All three tiers of government- federal, state and LGA - are democratically elected. The federal capital is Abuja. Nigeria is divided into six ecological zones, ranging from the semi-arid north-west to the savannah of the centre and south-west, and the high rainfall/rainforest areas of the south-south and southeast regions. Edem community in Nsukka, Local Government Area of Enugu State was the site. The state is in South Eastern Nigeria and Nsukka is one of the agricultural zones in the State. The majority of the inhabitants are farmers while a small proportion are civil servants and public servants. The land marks of Nsukka include hilly terrene.

Data collection and analysis. Secondary data were collected from Community Based Monitoring System (CBMS) Nigeria Project. The CBMS data is accessible at http://www.cbms. The CBMS database houses variables of about 5,000 rural households of Edem Nsukka, Enugu State, Nigeria; only households whose crop incomes were at least five thousand naira (\$33) were judged by the author as deriving their income from agrarian practices and hence were used for the study. Descriptive statistics, Pearson correlation and student t-test were used in data analysis. Also multinomial logistic regression was used to test the hypothesis.

\section{RESULTS AND DISCUSSIONS}

Sources of income. Agrarian households engage in a number of activities to generate income. Engagements in these activities are not mutually exclusive, it depends on whether the farmer has the resources to engage in such activity or not. Table 1 shows the daily mean and annual incomes of the selected households.

Agricultural labour and provision of other services in the rural area provided the inhabitants with the highest mean daily and annual income of $\$ 0.73$ and $\$ 264.7$, respectively. Some of the tedious agricultural labour that attracted higher income included land clearing, cultivation, harvesting and and processing of palm fruits. Some of the services rendered by these farmers included working at construction sites such as those of 
house and bridges construction. Only the younger ones can engage in these activities because of their energy demand.

Petty trading included marketing of agricultural produce such as fish, cereals and legumes. The marketing included those of fairly used wears, and other household utensils. Exploitation of forest resources provided a mean daily and annual income of $\$ 0.41$ and $\$ 150.67$, respectively. Forest resources exploited included shrubs, leaves, snails, bush meat and some timber products. This activity has implications for biodiversity conservation in addition to climate change. A very small proportion of the farmers benefited from dividends and pension services. Generally, on the average, all the farmers surveyed were poor. Their mean daily and annual incomes were $\$ 0.49$ and $\$ 177.43$, respectively. This is in consonance with the fact that average small scale farmer in Nigeria is poor.

Table 1 - Daily mean and annual income from different source

\begin{tabular}{|c|c|c|c|c|}
\hline Sources of income + & $\begin{array}{c}\text { Daily mean income } \\
(\$)\end{array}$ & $\begin{array}{l}\text { Annual mean income } \\
(\$)\end{array}$ & $\begin{array}{l}\text { Standard } \\
\text { deviation }\end{array}$ & $\begin{array}{c}\text { Number of } \\
\text { observations }+\end{array}$ \\
\hline Crop enterprises & 0.606393 & 221.3333 & 259.5169 & $2055(45.980)$ \\
\hline Livestock enterprises & 0.266667 & 97.33333 & 184.879 & $700(15.66)$ \\
\hline Petty trading & 0.577169 & 210.6667 & 352.0443 & $497(11.12)$ \\
\hline Forest exploitation & 0.412785 & 150.6667 & 203.8271 & $130(2.91)$ \\
\hline Labour/services & 0.725114 & 264.6667 & 553.2797 & $161(3.6)$ \\
\hline Remittance & 0.328767 & 120 & 253.373 & $879(19.67)$ \\
\hline Dividend/pension & 0.485845 & 177.3333 & 464.1092 & $47(1.05)$ \\
\hline Total & 0.486106 & 177.4286 & 437.369 & $4469(100)$ \\
\hline
\end{tabular}

Data base; + represent recording multiple responses, values in parenthesis are percentages.

Source: computed from CBMS-Nigreia.

Major activities considered under crop enterprises included cropping of maize, yams, cassava, cocoyam, rice, oil palm and some vegetables. Crop enterprises provided the largest amount of income from direct agricultural activity. It might be due to the fact that oil palm was included because Oreuja, Achike and Mkpado (2007) have noted that oil palm is a major source of income to farmers in South Eastern Nigeria. On the average, a mean daily income of $\$ 0.61$ and $\$ 221.3$ per annum respectively was recorded for the crop farmers. Type of enterprises considered under livestock included poultry business, piggery as well as sheep and goat rearing. Livestock enterprises provided the least income per farmer; the daily mean income was $\$ 0.27$ while the annual mean income was $\$ 97$ dollars. This further reflects on poverty of the community because this result indicates that livestock farmers are not making much money as livestock products are not in good demand. This has implications for nutrition.

Given the high prevalence of poverty among small scale farming households the possibility of individual equity financing of cleaner energy sources for agricultural activities such as irrigation is very remote. An arrangement had been made under the National Fadama Development Programme to assist such needy farmers by putting a framework for organizing them into groups called fadama user groups in place. Fadama programme is a composite agricultural transformation/development package. Fadama refers to wetlands. It is a Hausa word for wetland, riverine and valley-bottom (fadama). The Fadama programme provides grants for provision of agricultural inputs and machineries. In Nigeria the Fadama programme had helped a number of groups with irrigation pumps. Wind mill projects are usually used to provide water. The water can be for domestic and farm use (irrigation). The use of the fadama groups can be upscale irrigation projects involving wind mills in Nigeria.

In Malawi's southern region, the Smallholder Irrigation Project (SHIP) is helping farmers cope with effects of changing rainfall patterns. With funding from the African Development Bank, it is supplying treadle pumps to small-scale farmers so that they can use water from rivers, lakes and dams for their crops. The project, which is targeting 12,000 farmers, is also constructing dams to improve irrigation, and build new markets so that farmers can sell their produce more easily. The small-scale producers have formed groups and grow a range of crops, especially tomatoes, cabbages and onions. Some of them are already supplying local super markets chains. Extension officers advise and train far- 
mers on how to get the best out of land affected by water shortages (Spore, 2008b).

Rainwater harvesting and environmental sanitation are vital in Africa, where there is a serious shortage of reasonable priced water for agriculture. A number of effective and affordable techniques have been developed, but their diffusion remained limited. CTA organized a study visit on the issue, together with Margaf publishing and CREPA, a network promoting technologies for providing safe drinking water and sanitation in central and West Africa. The event was held in Burkina Faso, some 20 representatives from the public and private sector of 11 countries of West and Central Africa. At the end of the workshop in Burkina Faso, rain water harvesting and recycling waste for agricultural purposes was made to become more adaptable to the people (Spore, 2007). The provision of training is one way to build capacity for climate change adapta- tion, the opportunity can be exploited to encourage farmers acquire techniques for better resource management, mitigating and adapting to climate change.

Correlations and implications. Crop enterprises had significant positive correlation with use of electric generator, fire wood/charcoal and hydro electric power. Global emissions from deforestation and land-use change are estimated to account for $18 \%$ of total GHG emissions. LDCs are responsible for some $20 \%$ of this, making land-use change and forestry the only truly significant sources of emissions from LDCs in global terms (Eboh, 2011). Current debates over forestry and climate change mitigation centre on the development of a global scheme for reduced emissions from deforestation and degradation (REDD) under a post-2012 UNFCCC regime. Thus, advances in wood fuel are not the best option (Eboh, 2011).

Table 2 - Correlates of income from different sources to energy sources

\begin{tabular}{|c|c|c|c|c|c|}
\hline \multirow{2}{*}{ Sources of income } & \multicolumn{5}{|c|}{ Sources of energy } \\
\hline & $\begin{array}{c}\text { Electric } \\
\text { Generator }\end{array}$ & $\begin{array}{l}\text { Gas } \\
\text { cooker }\end{array}$ & Kerosene Stove & $\begin{array}{c}\text { Fire } \\
\text { wood/charcoal }\end{array}$ & $\begin{array}{c}\text { Hydro Electric } \\
\text { Power }\end{array}$ \\
\hline Crop enterprises & $\begin{array}{l}0.60 \\
(0.007) * *\end{array}$ & $\begin{array}{l}0.012 \\
(0.58) \mathrm{ns}\end{array}$ & $\begin{array}{l}0.037 \\
(0.091) \mathrm{ns}\end{array}$ & $\begin{array}{l}0.44 \\
(0.045) *\end{array}$ & $\begin{array}{l}0.47 \\
(0.037) *\end{array}$ \\
\hline $\begin{array}{l}\text { Livestock } \\
\text { Enterprises }\end{array}$ & $\begin{array}{l}0.057 \\
(0.135) \mathrm{ns}\end{array}$ & $\begin{array}{l}0.009 \\
(0.819) \mathrm{ns}\end{array}$ & $\begin{array}{l}0.80 \\
(0.035) *\end{array}$ & $\begin{array}{l}0.058 \\
(0.125)\end{array}$ & $\begin{array}{l}0.43 \\
(0.025) *\end{array}$ \\
\hline Petty trading & $\begin{array}{l}0.228 \\
(0.000) * *\end{array}$ & $\begin{array}{l}0.340 \\
(0.000) * *\end{array}$ & $\begin{array}{l}0.112 \\
(0.013) * *\end{array}$ & $\begin{array}{l}0.030 \\
(0.503) \mathrm{ns}\end{array}$ & $\begin{array}{l}0.053 \\
(0.252) \\
\end{array}$ \\
\hline Forest exploitation & $\begin{array}{l}0.183 \\
(0.333) \mathrm{ns}\end{array}$ & $\begin{array}{l}0.063 \\
(0.741) \mathrm{ns}\end{array}$ & $\begin{array}{l}0.030 \\
(0.664) \mathrm{ns}\end{array}$ & $\begin{array}{l}0.47 \\
(0.043) *\end{array}$ & $\begin{array}{l}0.68 \\
(0.001) * *\end{array}$ \\
\hline Labour/services & $\begin{array}{l}0.470 \\
(0.021) *\end{array}$ & $\begin{array}{l}0.013 \\
(0.904) \mathrm{ns}\end{array}$ & $\begin{array}{l}0.018 \\
(0.869) \mathrm{ns}\end{array}$ & $\begin{array}{l}0.069 \\
(0.521) \mathrm{ns}\end{array}$ & $\begin{array}{l}0.362 \\
(0.042) *\end{array}$ \\
\hline Remittance & $\begin{array}{l}0.397 \\
(0.025) *\end{array}$ & $\begin{array}{l}0.048 \\
(0.155) \mathrm{ns}\end{array}$ & $\begin{array}{l}0.031 \\
(0.358) \mathrm{ns}\end{array}$ & $\begin{array}{l}0.016 \\
(0.628)\end{array}$ & $\begin{array}{l}0.461 \\
(0.032) *\end{array}$ \\
\hline Dividend/pension & $\begin{array}{l}0.451 \\
(0.061) *\end{array}$ & $\begin{array}{l}0.008 \\
(0.92) \mathrm{ns}\end{array}$ & $\begin{array}{l}0.657 \\
(0.003) * *\end{array}$ & $\begin{array}{l}0.278 \\
(0.265) \mathrm{ns}\end{array}$ & $\begin{array}{l}0.425 \\
(0.022) *\end{array}$ \\
\hline Total & $\begin{array}{l}0.191 \\
(0.000) * *\end{array}$ & $\begin{array}{l}0.213 \\
(0.000) * *\end{array}$ & $\begin{array}{l}0.59 \\
(0.046) *\end{array}$ & $\begin{array}{l}0.044 \\
(0.142) \mathrm{ns}\end{array}$ & $\begin{array}{l}0.114 \\
(0.000) * *\end{array}$ \\
\hline
\end{tabular}

Values in parenthesis are levels of significance; $*$ and $* *$ represent significance at $5 \%$ and $1 \%$ levels, respectively; $n s$ represents non significance. Source: computed from CBMS-Nigreia.

Livestock enterprises had significant correlation with use of kerosene stove and electrical power. Livestock enterprises such as brood and sell in poultry require heating. This heating can be generated using kerosene stove and electrical power. The availability of hydro electrical power will reduce the use of kerosene stove by livestock farmers especially those engaging in brood and sale. Petty trading income had significant correlation with electric generator, gas stoves, and kerosene stove. Income from forest exploitation had significant correlation with fire wood/charcoal and hydro electrical power. Income from labour and rendering services is significantly related to use of generator and hydro electric power. Income from dividend and remittance were positively related to use of electrical generator and hydro electrical power.

The use of hydro electrical power needs reorientation to switch from carbon less efficient bulbs to more carbon efficient bulbs. This call for campaigns in the media and through change 
agents such as agricultural extension staff and provision of some tax incentives to importers of the carbon efficient bulbs and fluorescents tubes or subsidy for end users of the bulbs to make it more attractive to poor households. Ogbu (2010) reported that Imo Ekpo who is also the Acting Executive Director, Operations of the Niger Delta Basin Development Authority had an interactive session with the media in Port Harcourt, Rivers State where he canvassed that Nigeria should exploit her potentials in hydro generations in order to meet its target. The report states that $67 \%$ of power generation of the country comes from thermal stations while 33 per cent comes from hydro power stations, pointing out that since the global trend in power generation was tilting towards hydro generation, the country should also follow suit. In most parts of the world, countries are delving from thermal to hydro-power because of environmental issues. Hydro power generation gives cleaner energy in accordance with the Kyoto Protocol. There are plans to increase usage of other energy sources. The gas turbine plant is expected to boost the country's energy supply by 130 MW. Nigeria currently produces just below 3000 megawatts of electricity; use of solar energy is also on the increase. There are plans to increase hydropower supply through use of small hydropower in Nigeria. The Federal Ministry of Power - NEPA, currently has installed capacity of about 6000MW (Ogbu, 2010). In line with the current trend of limiting production and use of hydropower, due to effects of climate change on hydrology, there is need to re-evaluate the country's hydrology and its power generating capacity in the future to maintain sustainable development.

Climate-change is likely to alter river discharge, resulting in important impacts on water availability for in stream usage, particularly hydropower generation. Hydrological changes will directly affect the potential output of hydroelectric facilities - both those currently existing and possible future projects. There are large regional differences in the extent of hydropower development. In Africa, where little of the continent's hydropower potential has been developed, climate change simulations for the Batoka Gorge hydro-electric scheme on the Zambezi River projected a significant reduction in river flows (e.g., a decline in mean monthly flow from $3.21 \times 109$ $\mathrm{m} 3$ to $2.07 \times 109 \mathrm{~m} 3$ ) and declining power production (e.g., a decrease in mean monthly pro- duction from $780 \mathrm{GWh}$ to $613 \mathrm{GWh}$ ) (Harrison and Whittington, 2002).

Of particular interest for projections of water resources, with or without climate change, are possible changes in dam construction and decommissioning, water supply infrastructure, waste water treatment and reuse, desalination, pollutant emissions and land use, particularly with regard to irrigation. Irrespective of climate change, new dams are expected to be built in developing countries for hydropower generation as well as water supply, even though their number is likely to be small compared to the existing 45,000 large dams. However, the impacts of a possible future increase in hydropower demand have not been taken into account (World Commission on Dams, 2000; Scudder, 2005). In developed countries, the number of dams is very likely to remain stable, and some dams will be decommissioned. With increased temporal runoff variability due to climate change, increased water storage behind dams may be beneficial, especially where annual runoff does not decrease significantly. Consideration of environmental flow requirements may lead to further modification of reservoir operations so that the human use of water resources might be restricted. Climate change poses some threat on water resources and the need to develop other alternative energy sources such as solar, windmill, bio fuel can be better alternatives or at least sources of good compliments to the hydro-electric power. The use of solar energy in street lightering as already going on in Nigeria is a welcome development, besides the solar energy is low carbon source of energy, it will help to reduce the stress on water resources. This call for improved funding both international and national agencies interested in mitigating effects of climate change can exploit this opportunity.

Socio-economic variables and sources of energy. A multinomial regression was used to estimate the effects of selected socio economic variables on access of energy sources. The result is acceptable because of its significant chi-square value (20.42), high Log likelihood ratio (-40.25) and relatively high pseudo coefficient of determination (0.48). The result (Table 3) showed that income, age, education and house hold size affect choice of certain energy sources. For instance total income is a major determinant of use of electric generators and gas cooker, while advancement in age increases the probability to use 
firewood or charcoal. It is possible that increase in age is related to use of firewood and charcoal because must aged people return to their villages which are the rural areas close to forest resources where firewood and charcoal can easily be obtained, besides agriculture which is the occupation under consideration and majority of the farmers live in the rural area. Other factors which increase the probability to use fuel wood resources include household size; it is possible that large household size exerts more economic pressure that the households use the cheapest source available-fuel wood. It may be informative to not that level of education is negatively related to the probability to use fuel wood. Level of education also increases the probability to use kerosene fuel; this call for provision of more efficient kerosene stoves. The wide use of stove has been alluded to by Guozhu et al (2009) who studied energy consumption in Gansu Province Chaina, when they noted that space heating, especially heating Kang bed-stoves, accounts for more than half of living energy consumption, which uses biomass fuel and has negative impact on the eco- environment. The effects of income and education on use of electric generator which uses diesel or premium motor sprit and kerosene stove call for improved refinement of petroleum resources and use of less sulphur petroleum resources. In order to encourage people to preserve forest resources, their income need to be cushioned or the fuel pump price subsidized. The option with greater possibility is subsidizing of pump prices. This is in line with the concept of poverty reduction by providing subsidy on resources the poor consume. Obi (2007) advised that government should spend the sectors where the poor consume most of their output as a way of reducing poverty. Given that the base category is use of hydroelectric power showed that it is the most wildly used source of energy. This go to show that investment in sub sector or efforts to develop substitutes will be cost effective because of the number of people involved and the tradeoff can be estimated by measuring the net saved carbon emission due to policy and programme interventions.

Table 3 - Effects of socioeconomic variables on choice of sources of energy

\begin{tabular}{|c|c|c|c|c|}
\hline Variables & Generator & Gas & Kerosene & Wood \\
\hline Constant & $-2.866995(2.28)$ & $-4.310069(2.85)$ & $-2.574528(1.28)$ & $1.414991(0.39)$ \\
\hline Total income & $.000296(2.88)$ & $.000309(2.20)$ & $-00002.40(0.39)$ & $.0000535(0.15)$ \\
\hline Age & $.0062211(0.27)$ & $-.00577(0.09)$ & $.0169384(1.05)$ & $.0441297(1.74)$ \\
\hline Education & $.0220016(0.12)$ & $.3075262(0.61)$ & $.2015149(1.70)$ & $-2.07007(1.91)$ \\
\hline House hold size & $-.0000604(1.25)$ & $.0004721(1.23)$ & $5.76 \mathrm{e}-06(0.71)$ & $.002578(1.87)$ \\
\hline
\end{tabular}

$2 \mathrm{LR}$ chi2 $=20.42$; Prob $>$ chi2 $=0.0004 ;$ Log likelihood $=-40.255603$; Pseudo R2 = 0.4809; figures in parenthesis are t- values. Critical t-values: $1.65=\operatorname{sig}$ at 10 percent, $1.7=\operatorname{sig}$ at 5 percent. The base outcome is use of Hydro electric power.

\section{CONCLUSION}

The study has demonstrated that the average annual income of agrarian households from different sources such as crop farming, livestock farming, petty trading, forest exploitation, remittance and labour per day were below the poverty line of $\$ 1$ per day. It correlated income from these sources to access of sources of energy. It found significant correlation between use of electric generator with crop income, petty trading, remittance from Nigeria and abroad, respectively. Use of gas cooker was significantly correlated with petty trading, and total income. Use of kerosene stove was significantly correlated with livestock income, petty trading, remittance from Nigeria and total income respectively. Use of wood energy was significantly correlated to crop income. The source of energy that had the highest number of significant correlation was electrical energy (low carbon electrical energy). It showed the possibility of pooling resources as farmers group to attract a grant or by equity financing to build wind mills for irrigation. The study thus recommended the use of energy efficient bulbs to reduce $\mathrm{CO}_{2}$ emissions; this requires creating awareness to the rural dwellers of the need to make such change. Government should use solar energy for street lighting. Provisions of more efficient wood and kerosene stoves for rural women should be encouraged by philanthropists, government and non government organizations. Farmers should pool their resources to form groups in order to access more efficient energy sources that may be expensive for an individual 
poor farmer such as wind mill energy. It concluded by saying that poverty alleviation and environmental sustainability can be achieved by providing cleaner energy sources. Subsidy should be increased for pump prices to encourage conservation of forest resource.
Areas of future research. There may be need to quantify the volume of kerosene, gas and fuel used by these farmers in order to estimate the quantity of green house gas emitted by these households.

\section{REFERENCES}

Ogbu, A. 2010. Hydro power's solution to nation's electricity problems. This Day Newspaper, Thursday, 13th Jan., 2010.

Bates, B.C., Z.W. Kundzewicz, S. Wu and J.P. Palutikof, (eds). (2008). Climate Change and Water. Technical Paper of the Intergovernmental Panel on Climate Change, IPCC Secretariat, Geneva, $210 \mathrm{pp}$.

CAP (2003). The CAP \& Climate Change http://www.ifoam.org/about_ifoam/around_ world/eu group-

new/workareas/policy/php/factsheets/FS2theCAPandClimateChange-0614.pdf

CBN (Central Bank of Nigeria) (2008). SelfHelp Group Linkage programme At http://www.cenbank.org/devfin/17k.pdf

CEEPA (Centre for Environmental Economic Policy in Africa) (2002). Centre for Environmental and Economic policy in Africa. Climate change and Agriculture in Africa http://www.ceepa.co.za\%20\%20\%20Climat e/Change\%20\%20\%20index.html

DFID (2002). Energy for the poor: underpinning the MDGs. DFID, London

Eboh, E. (2011). Agro-Science and Policy Imperatives for Climate Change Mitigation and Adaptation. Keynote Address at the 10th Anniversary of Agro-Science Journal, Faculty of Agriculture, University of Nigeria, 7 July, 2011.

Fadama (National Fadama Development Programme) (2006). The Journey So Far: Second National Fadama Development Project

http://www.Fadama.org/nigeria/projects.pdf

Funde, M., J. Fjalland, H. M. Ravnborg and H. Egelyng (2009). Low Carbon Development and Poverty Alleviation Options for Development Cooperation in Energy, Agriculture and Forestry. Danish Institute for International Studies, DIIS , Report 2009:20 Copenhagen, Denmark.

Guozhu, Li, Shuwen Niu, Libang Ma, Xin Zhang
(2009) Assessment of environmental and economic costs of rural household energy consumption in Loess Hilly Region, Gansu Province, China Renewable Energy 34 (2009) 1438-1444.

Harrison, G.P. and H.W. Whittington, (2002). Susceptibility of the Batoka Gorge hydroelectric scheme to climate change. J. Hydrol., 264(1-4), pp. 230-241.

IFAD (International Fund for Agricultural Development) (2008). Soaring food prices and the rural poor: feedback from the field.

http://www.ifad.org/operations/food/food. htm

IFAD (International Fund for Agricultural Development) (2009). Enabling the poor to overcome poverty: country programme evaluation-Nigeria.

http://www.ifad.org/evaluation/public html/ eksyst/doc/agreement/pa/nigeria.htm

Intergovernmental Panel on Climate Change (IPCC) (2007). Synthesis Report: Summary for Policy Makers. Cambridge University Press, Cambridge, UK.

Molua E., T. Mwebaze, S. Kaisiromwe, R. Nkendah and M. Mkpado (2011). Review of the Effects of Climate Change on Smallholder Livestock Producers in Africa. A Project submitted for Climate Change Science and Modeling of Biophysical and Economic Impacts Course, Organized by World Institute for Development Economics Research of the United Nations University (UNU-WIDER) \& African Economic Research Consortium, August.

NPC (National Population commission) (2007). Census Results, Abuja Nigeria, April.

Oreuja, M., A. I. Achike and M. Mkpado (2007). Evaluation of farming system and informal insurance measures for optimum income of rural farmers in the rain forest zone of Nigeria. Journal of Agric. and Food Science, vol. 
5 (1), Pp. 53-65.

Obi, B.O. Fsical 2007 Policy and Poverty Alleviation: Some Policy Options for Nigeria AERC Research Paper 164.

Scudder, T., (2005) The future of large dams. Earthscan, London, 408 pp.

Spore (2007). Spreading the word about leaf meal. Spore No. 125, p. 6.

Spore (2008a) Smallholder irrigation projects. Spore No. 137, p. 9.

Spore (2008b) Selling ginger again. Spore No. 134, p. 5.

Spore (2006). Care free cassava. Spore No. 25, p. 7.
Spore (2010). Value chain finance. Spore 148, p. 2.

Spore (2010b). Reconstituting food aids policy to ensure food security. Spore, No. 147 p.5.

WDR (World Development Report) (2008) World Development Report, 2008.

World Commission on Dams (2000). Dams and Development: A New Framework for Decision-Making. Earthscan, London, 442 pp. 